\title{
Hemostasis alterations in metabolic syndrome (Review)
}

\author{
IVáN PALOMO ${ }^{1}$, MARCELO ALARCÓN ${ }^{1}$, RODRIGO MOORE-CARRASCO ${ }^{1}$ and JOSEP M. ARGILÉS ${ }^{2}$ \\ ${ }^{1}$ Department of Clinical Biochemistry and Immunohematology, Faculty of Health Sciences, Universidad de Talca, Chile; \\ ${ }^{2}$ Departament de Bioquimica i Biologia Molecular, Facultat de Biologia, Universitat de Barcelona, Barcelona, Spain
}

Received March 31, 2006; Accepted June 19, 2006

\begin{abstract}
Metabolic syndrome (MS) is characterized by the presence of at least three of the following alterations: enlargement of the waist diameter, higher levels of arterial pressure, low density lipoprotein cholesterol and glycemia, and reduction of high density lipoprotein cholesterol. The prevalence of MS reaches $23 \%$ in young adults, a percentage that increases with age. People with MS have a greater risk of suffering from cardiovascular disease (CVD). The physiopathologic alterations now found to exist in MS are diverse; among them is endothelial dysfunction, which triggers atherogenic lesions and hypercoagulability characterized by alterations of the coagulation factors and the regulatory proteins of fibrinolysis such as the plasminogen activator inhibitor (PAI-1). The increase in oxidative stress and/or the reactive oxygen species in patients with MS is partially related to the oxidation state of the lipoproteins, especially of the low density lipoproteins. This fact favors atherogenesis. Moreover, the oxidative stress produces alterations in the production of adipokines, cytokines secreted by the adipose tissues. The abnormality in the transport of lipoprotein diminishes the catabolism of the very low density lipoprotein (VLDL) and increases the catabolism of the high density lipoprotein (HDL), which creates insulin resistance. This process is associated with a lower concentration of adiponectin that in turn regulates the catabolism of VLDL and HDL; consequently increasing the flow of fatty acids from the adipose tissue to the liver and muscles. The proinflammatory cytokines, among them tumor necrosis factor $\alpha(\mathrm{TNF}-\alpha)$, are of great importance in MS regulating different processes and molecules such as PAI-1. PAI-1 is controlled by the group of transcription factors peroxisome proliferator-activated receptor (PPAR), especially by PPAR $\gamma$ and $\alpha$ ligands. In summary, MS includes multiple alterations related to insulin resistance at several levels: hepatic, muscular, adipose and vascular tissue (endothelium). The exact mechanism that underlies the
\end{abstract}

Correspondence to: Dr Iván Palomo, Department of Clinical Biochemistry and Immunohematology, Faculty of Health Sciences, Universidad de Talca, Mailbox 747, Talca, Chile

E-mail: ipalomo@utalca.cl

Key words: metabolic syndrome, hemostasis, thrombosis relationship between MS and CVD are not sufficiently known yet; pathogenic explanations are lacking for the mechanisms relating metabolic factors to insulin resistance and the association with the development of atherosclerosis and thrombosis. MS alterations and the main aspects related to homeostasis alterations are examined in this report.

\section{Contents}

1. General background

2. Endothelial dysfunction

3. Alterations in hemostasis and fibrinolysis

\section{General background}

Cardiovascular disease (CVD) is the main cause of death in the world representing around $30 \%$ of all deaths (1). It also constitutes an important factor in morbidity and incapacity (2). There are several CVD risk factors, both classic and emergent (3). Metabolic syndrome (MS) is characterized by a series of alterations that increase endothelial damage and atherothrombosis (4-6). MS includes multiple alterations related to insulin resistance involving hepatic, muscular, vascular (endothelial) and fatty tissue (7). The exact mechanisms of MS and CVD are not yet sufficiently well-known; they lack pathogenic explanations that relate the metabolic factors to insulin resistance, atherosclerosis development and thrombosis (risk of CVD).

The National Cholesterol Education Program (NCEP), in the year 2001, redefined the diagnostic approaches to MS in the Adult Treatment Panel III (ATP III) demanding the presence of at least 3 of the 5 following conditions (8): abdominal obesity (waist circumference: men, $>40$ inches; women, $>35$ inches), hypertriglyceridemia (>150 mg/dl), low levels of HDL (high density lipoprotein) cholesterol (c-HDL) $(<40 \mathrm{mg} / \mathrm{dl})$, arterial hypertension $(>130 / 85 \mathrm{~mm} \mathrm{Hg})$, and hyperglycemia ( $>100 \mathrm{mg} / \mathrm{dl}$ ). Besides these conditions, other alterations have been described for MS: hyperuricemia, coagulation alterations and high levels of plasminogen activator inhibitor type 1 (PAI-1).

The prevalence of MS varies according to the definition used to determine it, as well as age, sex, ethnic origin and lifestyle. In Chile, the National Survey of Health (2003) showed a prevalence of $22.6 \%$, without differences between men and women, but differing according to age: $17-24$ years (4.6\%), 
25-44 years (17.9\%), $45-64$ years $(36.5 \%)$ and over 65 years $(48 \%)$.

Individuals with glucose intolerance, abdominal fat, hypertriglyceridemia, and low levels of c-HDL have a greater risk of suffering CVD (9-11). This group of factors is part of MS, which is also denominated syndrome $\mathrm{X}$, insulin resistance syndrome, cardiovascular dysmetabolic syndrome and plurimetabolic syndrome (12-14). A high risk of CVD is associated with the rapid development of atherosclerosis which favors thrombosis (4-6).

Obesity is associated with an increase in free fatty acids and subsequently with increased glucogenolysis and hepatic gluconeogenesis, which leads to hyperglycemia. This in turn provokes hyperinsulinemia and, subsequently, insulin resistance.

Fatty tissue is at the moment considered an endocrine tissue that secretes several adipokines. Among these cytokines secreted by the adipose are adiponectin, leptin, resistin, tumor necrosis factor $\alpha$ (TNF- $\alpha$ ), interleukin-1 (IL-1), IL-6 and PAI-1. These molecules regulate metabolic aspects of carbohydrates and lipids, the endothelium, inflammatory processes, hemostasis, and others $(15,16)$. Thus, for example, some increase the secretion of proatherogenic cytokines, such as TNF- $\alpha$, while others such as adiponectin lower the synthesis of other cytokine protectors (7).

From a physiopathologic point of view, MS is characterized by dyslipidemia, endothelial dysfunction and alteration of coagulation or fibrinolysis.

\section{Endothelial dysfunction}

The vascular endothelium synthesizes vasoactive peptides, growth factors and cytokines. It regulates the balance between vasoconstriction and vasodilation, coagulation and fibrinolysis, platelet adhesion and aggregation, proliferation and apoptosis, and leukocyte adhesion and diapedesis (17). MS is associated with changes in the proliferation of smooth musculature cells and endothelial dysfunction (18). The endothelium is thus an important point of union between CVD and the metabolic pathways because hyperinsulinemia favors endothelial dysfunction (19) with which atherosclerosis is associated $(20,21)$.

Some cytokines, as previously indicated, favor endothelial function (22). The TNF- $\alpha$ that is increased in MS (23) inhibits lipoproteinlipase action, and activates oxidative stress and the high synthesis of proteins at the acute phase (24). IL-6 inhibits insulin signaling and activates endothelial cells (25), thus moderating inflammation; it also participates in the immune response and the increased expression of tissue factor (TF) in monocytes (26).

Cellular adhesion molecules are secreted on the surface of endothelial cells (EC) and, thus, can bind leukocytes which cross the intima $(27,28)$. VCAM-1 (vascular cell adhesion molecule-1) is not expressed constituently on the endothelium, but it can be regulated in vitro in response to TNF- $\alpha$, IL-4 and interferon- $\gamma$ (IFN- $\gamma$ ), cytokines that are synthesized by the adipose as well as other tissues. Soluble VCAM-1 (sVCAM-1) is in the serum of healthy people and an elevation of this is observed in such pathologies as autoimmune diseases, infections and inflammatory processes (29), and in patients with non-compensated hypertension (30). ICAM-1 (intercellular adhesion molecule-1) is expressed in EC when they are stimulated with IL-1, TNF- $\alpha$ and IFN- $\gamma$ (31). E-Selectin is expressed in EC only after activation by inflammatory cytokines such as IL- $1 \beta$, TNF- $\alpha$ or endotoxines.

Nitric oxide is a vasodilation molecule synthesized by the EC. The insulin increases the synthesis of endothelial NO synthase (eNOS), and the bioavailability of NO also increases, which is translated into an antiatherogenic action (32). Endothelial damage diminishes the synthesis of NO.

Endothelin-1 (ET-1) is synthesized by the endothelium, monocytes and macrophages; it produces vasoconstriction (33). It is increased in obesity, insulin resistance $(34,35)$, diabetes mellitus (36), HTA (37) and coronary disease associated with MS $(38,39)$.

Intracellular signals play an important role in endothelial activation. Nuclear factor $\kappa \mathrm{B}(\mathrm{NF \kappa B})$ is one of the most important mechanisms of endothelial activation (40). This and other transcription factors can be activated by tumor necrosis factor $\alpha$ (TNF- $\alpha$ ), IL-1, hyperglycemia, shear force, LDLox and oxidative stress, among other factors. NFkB can regulate the expression of genes that code for cytokines, eNOS, cyclooxygenase-2, CAMs, immune response, IL-8, acute phase proteins and metalloproteinase (41-43).

\section{Alterations in hemostasis and fibrinolysis}

The alterations of the hemostasis of MS that favor a prothrombotic state include modifications in the coagulation system, fibrinolytic system and platelets. Individuals with MS present an increase in the levels of factor VII, fibrinogen and von Willebrand Factor (FVW), increasing the risk of CVD (44).

In arterial thrombosis the platelets, tissue factor (expressed in monocytes and activated platelets) and microparticles that express anionic phospholipid (45) take on important actions.

The monocytes stimulated by oxidative stress can express TF (46) and they contribute in this way to the thrombogenic process increasing the risk of CVD. In the atheromatosus lesions the TF is located around the necrotic center rich in lipids, for it is assumed that low density lipoprotein cholesterol (c-LDL) and the oxidized lipids induce the expression of TF (47).

Microparticles (MP) are small membrane pieces, liberated from sanguine cells or EC during cellular activation or apoptosis (48-50), which anionic phospholipids and TF can expose with the activation of the coagulation system $(51,52)$. MP is bound to the cells via specific receptors inducing cellular activation with the liberation of TF and cytokines (53-55). In patients with diabetes type 2 with microvascular complications, an increase in derived platelet MP has been observed (56).

The alteration of fibrinolysis in MS is due fundamentally to an increment in the serum level of PAI-1. The proinflammatory cytokines participate in their overexpression, particularly in the adipose tissue (16). The increase of the concentration of PAI-1 can lead to arterial thrombosis increasing CVD in individuals with MS (57-59). Abdominal obesity is related to an increase in PAI-1 concentration, as much antigenic as functional (60). On the other hand, a healthy diet and loss of weight diminish these levels $(60,61)$. 


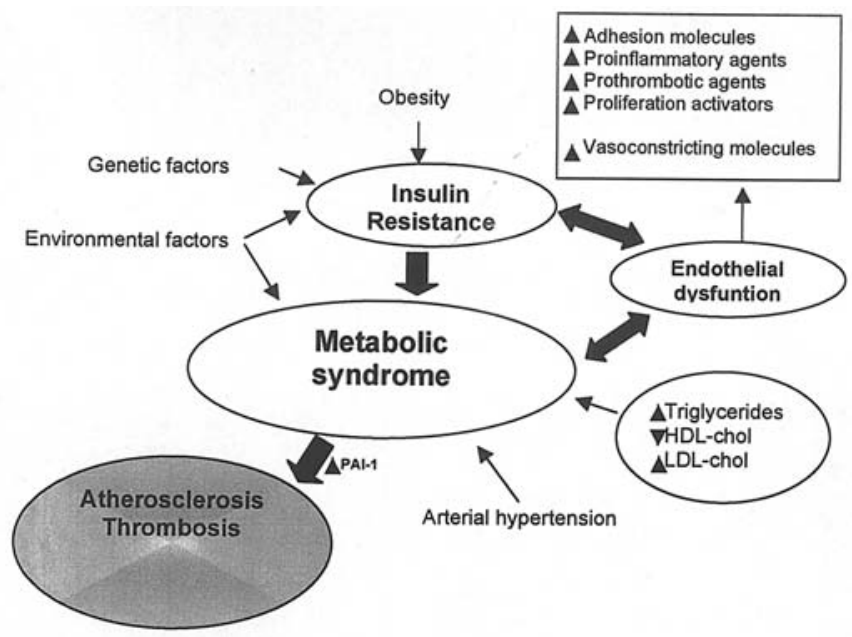

Figure 1. Factors that favor the prothrombotic state in Metabolic Syndrome. Ethiologic factors involved in metabolic syndrome and some of its consequences, where atherogenesis and thrombosis have a central role.

Lately, there have been attempts to integrate atherogenic and thrombogenic processes. Research has been centered on LDL, the molecule that initiated the atherosclerotic process. The platelets possess many receptors, among them, CD36 and oxidized LDL receptor-1 (LOX-1) (62), through which the oxidized LDL (LDLox) would produce platelet activation for phosphorylation of protein kinase p38 (p38MAPK) (63). LOX-1 are also expressed in endothelial cells, allowing the entrance of LDL to the intimal layer and the activation of these by means of the activation of NFKB (64). This receptor is also present in the monocytes where it would allow entrance by the LDL and consequently the formation of foamy cells (65).

LDLox is recognized by the scavenger receptors, CD36 and lectin-like LOX-1 (64) in the macrophages, giving origin to the foamy cells.

LDLox can activate the lymphocytes $\mathrm{T}$ and $\mathrm{B}$ generating immune response (66). LDLox can unite with the $\beta_{2}$ glycoprotein I ( $\left.\beta_{2} \mathrm{GPI}\right)$, generating new immunogenic epitopes and, subsequently, an autoimmune response that can increase the atherosclerosis and, finally, favor thrombosis $(67,68) . \beta_{2}$ GPI is a fundamental part of the antiphospholipid syndrome in which such antibodies as anticardiolipin are detected, which present a crossed reaction with LDLox $(69,70)$ being able to increase even more the atherogenic potential of the mentioned lipoprotein. These antibodies have been associated with acute myocardial infarction (AMI) (71), ischemic disease (72), arterial and venous thrombosis (73) and found in patients with systemic lupus erythematosus (74).

The increase of coagulation factors and tissue expression factor.

Factor VII and VIII. Individuals with MS have increased levels of factor VII, fibrinogen and von Willebrand factor (FVW), increasing the risk of CVD (44). The hyperfibrinogenemia is related to hyperinsulinism, suggesting a relationship independent from the inflammatory process. The loss of weight is associated with a decrease in the levels of factor VII, which is probably associated with a reduction of the TG.
Factor XIII. Positive correlation has been observed between the increase in the concentration of factor XIII, specifically subunit B, and MS, which could represent a CVD risk factor (75). Some association between the increased levels of FXIII and the polymorphism Val34Leu (75) have been demonstrated. However, it has been seen that the distribution of this polymorphism is similar in both patients with AMI and controls (76).

Expression of TF in monocytes and microparticles. The activity of the monocytes increases in endothelial inflammation in patients with CVD. In MS the superoxide radicals are associated with endothelial inflammation and the consequent activation of the monocytes (77). Microparticles (MP) are small membrane pieces, liberated from blood cells or EC during cellular activation or apoptosis (48-50). MP can expose anionic phospholipids, CD62P, CD42a and also TF, with the activation of the coagulation system $(51,52)$. MP bind to the cells via specific receptors that induce cellular activation with the liberation of TF and cytokines (53-55).

In the atheromatous lesions TF is located around the necrotic center rich in lipids, for it is assumed that c-LDL and the oxidized lipids induce the expression of TF (47). In contrast, PCR associated with inflammatory processes also induces the expression of TF on the cellular surfaces (78).

Type 2 diabetes is associated with atherosclerosis $(79,80)$. In patients with type 2 diabetes with poor metabolic control and microvascular complications an increment of derived platelet MP has been described (56). The TF expressed in microparticles, possibly of white cell origin, could be involved in different coagulation processes, such as signal transduction or angiogenesis (81).

TF can activate coagulation and it plays an important role in atherothrombosis; increased levels of TF have been associated with an increment in CVD risk (82). The expression of TF in the adipose tissue induced in obese mice deficient in leptin (ob/ob) has been demonstrated in addition to an association with an increase in the mRNA of the transforming growth factor $B$ (TGFB) $(83,84)$. In obese patients the thrombogenic state results from an increase in the levels of PAI-1 (85), factor VII and fibrinogen $(86,87)$. However, the role of circulating TF in relation to the death of obese patients has not been well studied. The increase in TF levels has been reported in patients with microvascular complications in diabetes and atherosclerosis favoring an increased risk of CVD (88-90).

Alterations of natural anticoagulants. The TF inhibitor (tissue factor pathway inhibitor, TFPI) is produced by EC (91) and it inhibits the complex FT/VIIa (91). The activity of TFPI has been associated with MS (92) and body mass index (BMI) (93). The activity of TFPI in patients with glucose intolerance and diabetes type 2 is found at high levels (94).

Decrease of fibrinolysis. In the course of diabetes intracellular hyperglycemia causes changes in the blood flow and an increase in vascular permeability. This is reflected by a decrease in NO activity and an increase in the activity of angiotensin II and ET-1 95. The angiotensin II produces an acute vasoconstriction that increases the blood pressure. ET-1 is also an important regulator of the vascular tone and it has been implicated in the pathogenesis of atherosclerosis. This 
in addition to the abnormalities in the extracellular matrix contribute to an irreversible increase in vascular permeability. Hyperglycemia does not only diminish the endothelial production of NO, which is an anti-atherogenic molecule, but it also increases the production of a potent fibrinolysis inhibitor, PAI-1 (95).

$P A I-1$. The atherothrombotic processes in MS are attributable to metabolic abnormalities, inflammation and alteration in the fibrinolysis; in the latter case by an increase in the levels of PAI-1. The synthesis of PAI-1 in adipocytes is regulated by insulin, glucocorticoides, angiotensin II, some fatty acids and mainly by adipokines such as TNF $\alpha$ and TGFB; catecholamines may inhibit their production. The proinflammatory cytokines have an important role in the oversecretion of PAI-1, particularly in the adipose tissue (16). Patients with MS present increased atherosclerosis and hypofibrinolysis $(4,11,96)$. The serum levels of PAI-1 are increased in patients with diabetes type 2 (97), AMI and stroke (98-100). High concentrations of PAI-1 and tPA reflect dysfunction of the fibrinolytic system that can lead to arterial thrombosis, increasing the risk of CVD in individuals with MS (57-59). Due to the complexity of the methods for measuring the function of the fibrinolytic system, the study of it has not been carried out on a large scale (101). There is evidence indicating that obesity, specifically abdominal obesity, is related to the increase in levels of PAI-1, as much antigenic as functional (60). Several pharmacological agents such as the tiazolidinediones, metformin and AT (1)-receptor antagonists reduce the production of PAI- 1 in the adipocytes. A healthy diet, loss of weight, and lifestyle modification decrease the inflammation and the levels of PAI-1 $(60,61)$.

There are 5 identified PAI-1 polymorphisms: two common polymorphisms, $-7654 \mathrm{G} / 5 \mathrm{G}$ and $-844 \mathrm{~A}>\mathrm{G}$, not located in the promoter; and three related, Ala15Thr (located in the peptide signal), Val17Ile and Asn195Ile (located in the B structure). In obese non-diabetic individuals, the first two polymorphisms are associated with high concentrations of glucose $(\mathrm{p}=0.006$ and $\mathrm{p}=0.0004$, for $-7654 \mathrm{G} / 5 \mathrm{G}$ and $-844 \mathrm{~A}>\mathrm{G}$, respectively) and insulin ( $\mathrm{p}=0.05$ and $\mathrm{p}=0.008$, for $7654 \mathrm{G} / 5 \mathrm{G}$ and -844 $\mathrm{A}>\mathrm{G}$, respectively). However, the $-844 \mathrm{~A}>\mathrm{G}$ was associated with hypotriglyceridemia $(\mathrm{p}=0.002)$ and high levels of $\mathrm{c}-\mathrm{HDL}$ $(\mathrm{p}=0.02)$. The promoter's two polymorphisms and the polymorphism Ala15Thr also showed association with CVD in diabetic persons (-765 4G/5G: 0.56/0.51, $\mathrm{p}=0.05$; $-844 \mathrm{~A}>\mathrm{G}$ : 0.63/0.57, p=0.02; Ala15Thr: 0.91/0.88, p=0.04). In summary, these polymorphisms increase the risk of CVD in diabetic individuals (102).

TAFI. Positive correlation has been observed between the levels of insulin and TAFI (thrombin-activatable fibrinolysis inhibitor) (103) and positive correlation has been observed between the levels of TAFI in diabetic patients v/s normal individuals (104); however, studies demonstrating these associations are scarce.

Although, previous studies have documented that the fibrinolysis markers are abnormal in MS, it is not clear whether these abnormalities reflect a fibrinolytic dysfunction or they are simply a response to the vascular damage (14). The presence and degree of the fibrinolytic dysfunction in people with MS, and whether this dysfunction can explain the increase in CVD in this group, must be determined.

\section{References}

1. Anuario Estadistico, Dirección del Servicio de Salud del Maule.

2. Instituto nacional de Estadística. Anuario de Demografía 2000. INE, Chile, 2000.

3. Alexander CM, Landsman PB, Teutsch SM and Haffner SM: NCEP-defined metabolic syndrome, diabetes, and prevalence of coronary heart disease among NHANES III participants age 50 years and older. Diabetes 52: 1210-1214, 2003.

4. Hulthe J, Bokemark L, Wikstrand J and Fagerberg B: The metabolic syndrome, LDL particle size, and atherosclerosis: the Atherosclerosis and Insulin Resistance (AIR) study. Arterioscler Thromb Vasc Biol 20: 2140-2147, 2000.

5. Sakkinen PA, Wahl P, Cushman M, Lewis MR and Tracy RP: Clustering of procoagulation, inflammation, and fibrinolysis variables with metabolic factors in insulin resistance syndrome. Am J Epidemiol 152: 897-907, 2000.

6. Juhan-Vague I, Alessi MC and Vague P: Increased plasma plasminogen activator inhibitor 1 levels. A possible link between insulin resistance and atherothrombosis. Diabetologia 34: 457-462, 1991.

7. Fletcher B and Lamendola C: Insulin resistance syndrome. J Cardiovasc Nurs 19: 339-345, 2004.

8. Third report of the National Cholesterol Education Program (NCEP) expert panel on detection, evaluation, and treatment of high blood cholesterol in adults (Adult Treatment Panel III) final report. Circulation 106: 3143-3421, 2002.

9. Reaven GM: Banting lecture 1988. Role of insulin resistance in human disease. Diabetes 37: 1595-1607, 1988.

10. Liese AD, Mayer-Davis EJ and Haffner SM: Development of the multiple metabolic syndrome: an epidemiologic perspective. Epidemiol Rev 20: 157-172, 1998.

11. Meigs JB, Mittleman MA, Nathan DM, Tofler GH, Singer DE, Murphy-Sheehy PM, Lipinska I, D'Agostino RB and Wilson PW: Hyperinsulinemia, hyperglycemia, and impaired hemostasis: the Framingham Offspring Study. JAMA 283: 221-228, 2000.

12. Ford ES, Giles WH and Dietz WH: Prevalence of the metabolic syndrome among US adults: findings from the third National Health and Nutrition Examination Survey. JAMA 287: 356-359, 2002.

13. Grundy SM: Obesity, metabolic syndrome, and coronary atherosclerosis. Circulation 105: 2696-2698, 2002.

14. Anand SS, Yi Q, Gerstein H, Lonn E, Jacobs R, Vuksan V, Teo K, Davis B, Montague P and Yusuf S: Relationship of metabolic syndrome and fibrinolytic dysfunction to cardiovascular disease. Circulation 108: 420-425, 2003.

15. Trayhurn P and Beattie JH: Physiological role of adipose tissue: white adipose tissue as an endocrine and secretory organ. Proc Nutr Soc 60: 329-339, 2001.

16. Beltowski J: Adiponectin and resistin - new hormones of white adipose tissue. Med Sci Monit 9: RA55-RA61, 2003.

17. Baumgartner-Parzer SM and Waldhausl WK: The endothelium as a metabolic and endocrine organ: its relation with insulin resistance. Exp Clin Endocrinol Diabetes 109 (suppl 2): S166-S179, 2001.

18. Bonetti PO, Lerman LO and Lerman A: Endothelial dysfunction: a marker of atherosclerotic risk. Arterioscler Thromb Vasc Biol 23: 168-175, 2003.

19. Mather KJ, Verma S and Anderson TJ: Improved endothelial function with metformin in type 2 diabetes mellitus. J Am Coll Cardiol 37: 1344-1350, 2001

20. Verma S and Anderson TJ: Fundamentals of endothelial function for the clinical cardiologist. Circulation 105: 546-549, 2002.

21. Kharbanda RK and Deanfield JE: Functions of the healthy endothelium. Coron Artery Dis 12: 485-491, 2001.

22. Ouchi N, Kihara S, Arita Y, Okamoto Y, Maeda K, Kuriyama H, Hotta K, Nishida M, Takahashi M, Muraguchi M, Ohmoto Y, Nakamura T, Yamashita S, Funahashi T and Matsuzawa Y: Adiponectin, an adipocyte-derived plasma protein, inhibits endothelial NF-kappaB signaling through a cAMP-dependent pathway. Circulation 102: 1296-1301, 2000.

23. Ferroni P, Basili S, Falco A and Davi G: Inflammation, insulin resistance, and obesity. Curr Atheroscler Rep 6: 424-431, 2004.

24. Chu NF, Spiegelman D, Hotamisligil GS, Rifai N, Stampfer M and Rimm EB: Plasma insulin, leptin, and soluble TNF receptors levels in relation to obesity-related atherogenic and thrombogenic cardiovascular disease risk factors among men. Atherosclerosis 157: 495-503, 2001. 
25. Yudkin JS, Stehouwer CD, Emeis JJ and Coppack SW: Creactive protein in healthy subjects: associations with obesity, insulin resistance, and endothelial dysfunction: a potential role for cytokines originating from adipose tissue? Arterioscler Thromb Vasc Biol 19: 972-978, 1999.

26. Weisberg SP, McCann D, Desai M, Rosenbaum M, Leibel RL and Ferrante AW Jr: Obesity is associated with macrophage accumulation in adipose tissue. J Clin Invest 112: 1796-1808, 2003.

27. Libby P, Ridker PM and Maseri A: Inflammation and atherosclerosis. Circulation 105: 1135-1143, 2002.

28. Cybulsky MI, Iiyama K, Li H, Zhu S, Chen M, Iiyama M, Davis V, Gutierrez-Ramos JC, Connelly PW and Milstone DS: A major role for VCAM-1, but not ICAM-1, in early atherosclerosis. J Clin Invest 107: 1255-1262, 2001.

29. Kuryliszyn-Moskal A, Klimiuk PA and Sierakowski S: Serum soluble adhesion molecules - sICAM-1, sVCAM-1, sE-selectin in patients with systemic rheumatoid arthritis. Pol Merkuriusz Lek 17: 353-356, 2004.

30. Palomo I, Marin P, Alarcon M, Gubelin G, Vinambre X, Mora E and Icaza G: Patients with essential hypertension present higher levels of sE-selectin and sVCAM-1 than normotensive volunteers. Clin Exp Hypertens 25: 517-523, 2003.

31. Witkowska AM and Borawska MH: Soluble intercellular adhesion molecule-1 (sICAM-1): an overview. Eur Cytokine Netw 15: 91-98, 2004.

32. Barbato JE, Zuckerbraun BS, Overhaus M, Raman KG and Tzeng E: Nitric oxide modulates vascular inflammation and intimal hyperplasia in insulin-resistance and the metabolic syndrome. Am J Physiol Heart Circ Physiol, 2005.

33. Yanagisawa M, Kurihara H, Kimura S, Tomobe Y, Kobayashi M, Mitsui Y, Yazaki Y, Goto K and Masaki T: A novel potent vasoconstrictor peptide produced by vascular endothelial cells Nature 332: 411-415, 1988

34. Ferri C, Bellini C, Desideri G, Di Francesco L, Baldoncini R, Santucci A and De Mattia G: Plasma endothelin-1 levels in obese hypertensive and normotensive men. Diabetes 44: 431-436, 1995.

35. Ferri C, Bellini C, Desideri G, Baldoncini R, Properzi G Santucci A and De Mattia G: Circulating endothelin-1 levels in obese patients with the metabolic syndrome. Exp Clin Endocrinol Diabetes 105 (suppl 2): 38-40, 1997.

36. Hopfner RL and Gopalakrishnan V: Endothelin: emerging role in diabetic vascular complications. Diabetologia 42: 1383-1394, 1999.

37. Krum H, Viskoper RJ, Lacourciere Y, Budde M and Charlon V: The effect of an endothelin-receptor antagonist, bosentan, on blood pressure in patients with essential hypertension. Bosentan Hypertension Investigators. N Engl J Med 338: 784-790, 1998.

38. Kaski JC, Elliott PM, Salomone O, Dickinson K, Gordon D, Hann $\mathrm{C}$ and Holt DW: Concentration of circulating plasma endothelin in patients with angina and normal coronary angiograms. Br Heart J 74: 620-624, 1995.

39. Piatti P, Fragasso G, Monti LD, Caumo A, Van Phan C, Valsecchi G, Costa S, Fochesato E, Pozza G, Pontiroli AE and Chierchia S: Endothelial and metabolic characteristics of patients with angina and angiographically normal coronary arteries: comparison with subjects with insulin resistance syndrome and normal controls. J Am Coll Cardiol 34: 1452-1460, 1999.

40. Costelli P, Muscaritoli M, Bossola M and Moore-Carrasco R, Crepaldi S, Grieco G, Autelli R, Bonelli G, Pacelli F, LopezSoriano FJ, Argiles JM, Doglietto GB, Baccino FM, Rossi Fanelli F: Skeletal muscle wasting in tumor-bearing rats is associated with MyoD down-regulation. Int J Oncol 26: 1663$1668,2005$.

41. Westra J, Kuldo JM, van Rijswijk MH, Molema G and Limburg PC: Chemokine production and E-selectin expression in activated endothelial cells are inhibited by p38 MAPK (mitogen activated protein kinase) inhibitor RWJ 67657. Int Immunopharmacol 5: 1259-1269, 2005

42. Hemmrich K, Suschek CV, Lerzynski G and Kolb-Bachofen V: iNOS activity is essential for endothelial stress gene expression protecting against oxidative damage. J Appl Physiol 95: 1937-1946, 2003.

43. Li QQ, Bever CT, Burt DR, Judge SI and Trisler GD: Induction of RANTES chemokine expression in human astrocytic cells is dependent upon activation of $N-\kappa B$ transcription factor. Int $\mathrm{J}$ Mol Med 7: 527-533, 2001.
44. Lansbury AJ, Grant PJ and Catto AJ: Atherothrombotic risk factors in subjects with a family history of stroke. Cerebrovasc Dis 14: 153-160, 2002.

45. Pereira J, Soto M, Palomo I, Ocqueteau M, Coetzee LM, Astudillo S, Aranda E and Mezzano D: Platelet aging in vivo is associated with activation of apoptotic pathways: studies in a model of suppressed thrombopoiesis in dogs. Thromb Haemost 87: 905-909, 2002.

46. Moreno PR and Fuster V: New aspects in the pathogenesis of diabetic atherothrombosis. J Am Coll Cardiol 44: 2293-2300, 2004.

47. Ohkura N, Hiraishi S, Itabe H, Hamuro T, Kamikubo Y, Takano T, Matsuda J and Horie S: Oxidized phospholipids in oxidized low-density lipoprotein reduce the activity of tissue factor pathway inhibitor through association with its carboxyterminal region. Antioxid Redox Signal 6: 705-712, 2004.

48. George JN, Thoi LL, McManus LM and Reimann TA: Isolation of human platelet membrane microparticles from plasma and serum. Blood 60: 834-840, 1982.

49. Nieuwland R, Berckmans RJ, Rotteveel-Eijkman RC, Maquelin KN, Roozendaal KJ, Jansen PG, ten Have K, Eijsman L, Hack CE and Sturk A: Cell-derived microparticles generated in patients during cardiopulmonary bypass are highly procoagulant. Circulation 96: 3534-3541, 1997.

50. Combes V, Simon AC, Grau GE, Arnoux D, Camoin L, Sabatier F, Mutin M, Sanmarco M, Sampol J and Dignat-George F: In vitro generation of endothelial microparticles and possible prothrombotic activity in patients with lupus anticoagulant. J Clin Invest 104: 93-102, 1999

51. Barry OP and FitzGerald GA: Mechanisms of cellular activation by platelet microparticles. Thromb Haemost 82: 794-800, 1999.

52. Giesen PL, Rauch U, Bohrmann B, Kling D, Roque M, Fallon JT, Badimon JJ, Himber J, Riederer MA and Nemerson Y: Bloodborne tissue factor: another view of thrombosis. Proc Natl Acad Sci USA 96: 2311-2315, 1999.

53. Mesri $M$ and Altieri DC: Leukocyte microparticles stimulate endothelial cell cytokine release and tissue factor induction in a JNK1 signaling pathway. J Biol Chem 274: 23111-23118, 1999.

54. Barry OP, Pratico D, Savani RC and FitzGerald GA: Modulation of monocyte-endothelial cell interactions by platelet microparticles. J Clin Invest 102: 136-144, 1998.

55. Barry OP, Pratico D, Lawson JA and FitzGerald GA Transcellular activation of platelets and endothelial cells by bioactive lipids in platelet microparticles. J Clin Invest 99 2118-2127, 1997

56. Omoto $\mathrm{S}$, Nomura $\mathrm{S}$, Shouzu A, Hayakawa T, Shimizu $H$, Miyake Y, Yonemoto T, Nishikawa M, Fukuhara S and Inada M: Significance of platelet-derived microparticles and activated platelets in diabetic nephropathy. Nephron 81: 271-277, 1999.

57. Kohler HP and Grant PJ: Plasminogen-activator inhibitor type 1 and coronary artery disease. N Engl J Med 342: 1792-1801, 2000.

58. Hamsten A, Wiman B, de Faire U and Blomback M: Increased plasma levels of a rapid inhibitor of tissue plasminogen activator in young survivors of myocardial infarction. N Engl J Med 313: $1557-1563,1985$.

59. Ridker PM, Vaughan DE, Stampfer MJ, Manson JE and Hennekens $\mathrm{CH}$ : Endogenous tissue-type plasminogen activator and risk of myocardial infarction. Lancet 341: 1165-1168, 1993.

60. Skurk T and Hauner H: Obesity and impaired fibrinolysis: role of adipose production of plasminogen activator inhibitor-1. Int $\mathbf{J}$ Obes Relat Metab Disord 28: 1357-1364, 2004

61. Muscelli E, Camastra S, Catalano C, Galvan AQ, Ciociaro D, Baldi $S$ and Ferrannini E: Metabolic and cardiovascular assessment in moderate obesity: effect of weight loss. J Clin Endocrinol Metab 82: 2937-2943, 1997.

62. Puccetti L, Sawamura T, Pasqui AL, Pastorelli M, Auteri A and Bruni F: Atorvastatin reduces platelet-oxidized-LDL receptor expression in hypercholesterolaemic patients. Eur J Clin Invest 35: 47-51, 2005 .

63. Korporaal SJ, Relou IA, van Eck M, Strasser V, Bezemer M, Gorter G, van Berkel TJ, Nimpf J, Akkerman JW and Lenting PJ: Binding of low density lipoprotein to platelet apolipoprotein $\mathrm{E}$ receptor $2^{\prime}$ results in phosphorylation of p38MAPK. J Biol Chem 279: 52526-52534, 2004.

64. Chen M, Masaki T and Sawamura T: LOX-1, the receptor for oxidized low-density lipoprotein identified from endothelial cells: implications in endothelial dysfunction and atherosclerosis. Pharmacol Ther 95: 89-100, 2002. 
65. Sakurai K and Sawamura T: Stress and vascular responses: endothelial dysfunction via lectin-like oxidized low-density lipoprotein receptor-1: close relationships with oxidative stress. J Pharmacol Sci 91: 182-186, 2003.

66. Stemme S, Faber B, Holm J, Wiklund O, Witztum JL and Hansson GK: T lymphocytes from human atherosclerotic plaques recognize oxidized low density lipoprotein. Proc Natl Acad Sci USA 92: 3893-3897, 1995.

67. Berliner JA, Territo MC, Sevanian A, Ramin S, Kim JA, Bamshad B, Esterson M and Fogelman AM: Minimally modified low density lipoprotein stimulates monocyte endothelial interactions. J Clin Invest 85: 1260-1266, 1990.

68. Matsuura E and Lopez LR: Are oxidized LDL/beta2glycoprotein I complexes pathogenic antigens in autoimmunemediated atherosclerosis? Clin Dev Immunol 11: 103-111, 2004.

69. Horkko S, Olee T, Mo L, Branch DW, Woods VL Jr, Palinski W, Chen PP and Witztum JL: Anticardiolipin antibodies from patients with the antiphospholipid antibody syndrome recognize epitopes in both beta(2)-glycoprotein 1 and oxidized low-density lipoprotein. Circulation 103: 941-946, 2001.

70. Amengual O, Atsumi T, Khamashta MA, Tinahones F and Hughes GR: Autoantibodies against oxidized low-density lipoprotein in antiphospholipid syndrome. Br J Rheumatol 36: 964-968, 1997.

71. Vaarala O, Manttari M, Manninen V, Tenkanen L, Puurunen M, Aho $\mathrm{K}$ and Palosuo T: Anti-cardiolipin antibodies and risk of myocardial infarction in a prospective cohort of middle-aged men. Circulation 91: 23-27, 1995.

72. Klemp P, Cooper RC, Strauss FJ, Jordaan ER, Przybojewski JZ and Nel N: Anti-cardiolipin antibodies in ischaemic heart disease. Clin Exp Immunol 74: 254-257, 1988.

73. Palomo I, Pereira J, Alarcon M, Vasquez M, Pinochet C, Velez MT, Sandoval J, Icaza G and Pierangeli S: Prevalence and isotype distribution of antiphospholipid antibodies in unselected Chilean patients with venous and arterial thrombosis. Clin Rheumatol 23: 129-133, 2004.

74. Palomo I, Pereira J, Alarcon M, Larrain AM, Pinochet C, Vasquez M, Velez MT, Leon M, Espinola R and Pierangeli S: Antiphospholipid antibodies in Chilean patients with systemic lupus erythematosus. J Lab Clin Med 140: 336-341, 2002.

75. Mills JD, Mansfield MW and Grant PJ: Factor XIII-circulating levels and the Val34Leu polymorphism in the healthy male relatives of patients with severe coronary artery disease. Thromb Haemost 87: 409-414, 2002.

76. Franco RF, Pazin-Filho A, Tavella MH, Simoes MV, MarinNeto JA and Zago MA: Factor XIII val34leu and the risk of myocardial infarction. Haematologica 85: 67-71, 2000.

77. Lin CP, Lin WT, Leu HB, Wu TC and Chen JW: Differential mononuclear cell activity and endothelial inflammation in coronary artery disease and cardiac syndrome X. Int J Cardiol 89: 53-62, 2003.

78. Venugopal SK, Devaraj S and Jialal I: Effect of C-reactive protein on vascular cells: evidence for a proinflammatory, proatherogenic role. Curr Opin Nephrol Hypertens 14: 33-37, 2005.

79. Kannel WB and McGee DL: Diabetes and cardiovascular risk factors: the Framingham study. Circulation 59: 8-13, 1979.

80. Stamler J, Vaccaro O, Neaton JD and Wentworth D: Diabetes, other risk factors, and 12-yr cardiovascular mortality for men screened in the Multiple Risk Factor Intervention Trial. Diabetes Care 16: 434-444, 1993.

81. Caine GJ, Harris AL, Christodoulos K, Lip GY and Blann AD: Analysis of combination anti-angiogenesis therapy on markers of coagulation, platelet activation and angiogenesis in patients with advanced cancer. Cancer Lett 219: 163-167, 2005.

82. Viles-Gonzalez JF, Anand SX, Zafar MU, Fuster V and Badimon JJ: Tissue factor coagulation pathway: a new therapeutic target in atherothrombosis. J Cardiovasc Pharmacol 43 : 669-676, 2004

83. Samad F, Pandey M and Loskutoff DJ: Regulation of tissue factor gene expression in obesity. Blood 98: 3353-3358, 2001.

84. Samad F, Yamamoto K, Pandey M and Loskutoff DJ: Elevated expression of transforming growth factor-beta in adipose tissue from obese mice. Mol Med 3: 37-48, 1997.
85. Juhan-Vague I and Alessi MC: PAI-1, obesity, insulin resistance and risk of cardiovascular events. Thromb Haemost 78: 656-660, 1997.

86. Kario K, Matsuo T, Kobayashi H, Matsuo M, Sakata T and Miyata T: Activation of tissue factor-induced coagulation and endothelial cell dysfunction in non-insulin-dependent diabetic patients with microalbuminuria. Arterioscler Thromb Vasc Biol 15: 1114-1120, 1995 .

87. Licata G, Scaglione R, Avellone G, Ganguzza A, Corrao S, Arnone S and Di Chiara T: Hemostatic function in young subjects with central obesity: relationship with left ventricular function. Metabolism 44: 1417-1421, 1995.

88. Lemieux S: Contribution of visceral obesity to the insulin resistance syndrome. Can J Appl Physiol 26: 273-290, 2001.

89. Garrison RJ, Higgins MW and Kannel WB: Obesity and coronary heart disease. Curr Opin Lipidol 7: 199-202, 1996.

90. Lamon-Fava S, Wilson PW and Schaefer EJ: Impact of body mass index on coronary heart disease risk factors in men and women. The Framingham Offspring Study. Arterioscler Thromb Vasc Biol 16: 1509-1515, 1996.

91. Sajadi S, Ezekowitz MD, Dhond A and Netrebko P: Tissue factor pathway inhibitors as a novel approach to antithrombotic therapy. Drug News Perspect 16: 363-369, 2003.

92. Morange PE, Renucci JF, Charles MA, Aillaud MF, Giraud F, Grimaux M and Juhan-Vague I: Plasma levels of free and total TFPI, relationship with cardiovascular risk factors and endothelial cell markers. Thromb Haemost 85: 999-1003, 2001.

93. Kopp CW, Kopp HP, Steiner S, Kriwanek S, Krzyzanowska K, Bartok A, Roka R, Minar E and Schernthaner G: Weight loss reduces tissue factor in morbidly obese patients. Obes Res 11: 950-956, 2003

94. Leurs PB, Stolk RP, Hamulyak K, Van Oerle R, Grobbee DE and Wolffenbuttel BH: Tissue factor pathway inhibitor and other endothelium-dependent hemostatic factors in elderly individuals with normal or impaired glucose tolerance and type 2 diabetes. Diabetes Care 25: 1340-1345, 2002.

95. Brownlee M: Biochemistry and molecular cell biology of diabetic complications. Nature 414: 813-820, 2001.

96. Beckman JA, Creager MA and Libby P: Diabetes and atherosclerosis: epidemiology, pathophysiology, and management. JAMA 287: 2570-2581, 2002 .

97. Sobel BE, Woodcock-Mitchell J, Schneider DJ, Holt RE, Marutsuka $\mathrm{K}$ and Gold $\mathrm{H}$ : Increased plasminogen activator inhibitor type 1 in coronary artery atherectomy specimens from type 2 diabetic compared with nondiabetic patients: a potential factor predisposing to thrombosis and its persistence. Circulation 97: 2213-2221, 1998 .

98. Thompson SG, Kienast J, Pyke SD, Haverkate F and van de Loo JC: Hemostatic factors and the risk of myocardial infarction or sudden death in patients with angina pectoris. European Concerted Action on Thrombosis and Disabilities Angina Pectoris Study Group. N Engl J Med 332: 635-641, 1995.

99. Hamsten A, de Faire U, Walldius G, Dahlen G, Szamosi A, Landou C, Blomback M and Wiman B: Plasminogen activator inhibitor in plasma: risk factor for recurrent myocardial infarction. Lancet 2: 3-9, 1987.

100. Meade TW, Ruddock V, Stirling Y, Chakrabarti R and Miller GJ: Fibrinolytic activity, clotting factors, and long-term incidence of ischaemic heart disease in the Northwick Park Heart Study. Lancet 342: 1076-1079, 1993.

101. Womack CJ, Ivey FM, Gardner AW and Macko RF: Fibrinolytic response to acute exercise in patients with peripheral arterial disease. Med Sci Sports Exerc 33: 214-219, 2001

102. Lopes C, Dina C, Durand E and Froguel P: PAI-1 polymorphisms modulate phenotypes associated with the metabolic syndrome in obese and diabetic Caucasian population. Diabetologia 46: 1284-1290, 2003

103. Aubert H, Frere C, Aillaud MF, Morange PE, Juhan-Vague I and Alessi MC: Weak and non-independent association between plasma TAFI antigen levels and the insulin resistance syndrome. J Thromb Haemost 1: 791-797, 2003.

104. Hori Y, Gabazza EC, Yano Y, Katsuki A, Suzuki K, Adachi Y and Sumida Y: Insulin resistance is associated with increased circulating level of thrombin-activatable fibrinolysis inhibitor in type 2 diabetic patients. J Clin Endocrinol Metab 87: 660-665, 2002. 